\title{
МЕТОДОЛОГІЯ ТЕАТРОЗНАВЧОГО ДОСЛІДЖЕННЯ ВОЛОДИМИРА ПЕРЕТЦА
}

У статті здійснено спробу визначити методологічні прийоми Володимира Перетиа на основі аналізу його праџь із історії театру. Охарактеризовано структурні особливості досліджень, окреслено їхнє співвідношення з теоретичними конщепціями вченого. Спираючись на дослідження вченого у різних жанрах (статті, рецензії, монографії, публікації стародруків тощо), визначено чотирнадиять ознак, щзо притаманні усім його працям в иарині театрознавства.

Ключові слова: Володимир Перети, історія театру, методологія Володимира Перетиа, методологія театрознавства.

В статье предпринята попытка определить методологические приемы Владимира Перетиа на основе анализа его работ по истории театра. Охарактеризованы структурные особенности исследований, определено их соотношение с теоретическими конщепџиями ученого. Опираясь на исследования ученого в различных жанрах (статьи, рецензии, монографии, публикации старопечати и т.n.), определены четырнадиать признаков, присущих его трудам в области театроведения.

Ключевые слова: Владимир Перети, история театра, методология Владимира Перетиа, методология театроведения.

The article attempts to determine Vladimir Peretz methodological techniques on the basis of analysis of his theatre history works. The research structural features are characterized, their relationship with the scientist's theoretical concepts is outlined. Fourteen features that are inherent in all his works in the field of theater studies are determined, based on scientist's research in different genres (articles, reviews, monographs, publications of the early printed books, etc.).

Key words: Volodumur Peretz, theatre history, Volodumur Peretz methodology, theater study methodology.

Постановка проблеми. Роль Володимира Перетца у формуванні методології театрознавчого дослідження сьогодні визнається беззаперечно [1, $17 ; 2,132-134 ; 3]$. Однак упроваджені ним принципи дослідження у царині театрознавства описуються надзвичайно суперечливо: як типологізація, історико-літературний підхід, академічний еклектизм, соціологізм, формалізм, формально-естетичний метод, позитивізм, формалістична чи формально-поетикальна школа, діалектичний марксистський метод, технологізм, міждисциплінарний підхід тощо. Незважаючи на суперечливість оцінок і власної «доволі скромної думки» Перетца стосовно власних досліджень 3 історії театру [4, 493], сучасні дослідники обгрунтовують необхідність «виокремити в історії вивчення раннього російського театру і драматургії особливий, “перетцівський” період» $[4,489]$.
Аналіз останніх досліджень та публікацій. Останніми десятиліттями різнопланова наукова діяльність Володимира Перетца дедалі частіше стає предметом дослідження філологів і культурологів (Г. Александрова, С. Міщук, С. Росовецький, О. Сліпушко, І. Чернова та ін.). Внесок Перетца у театрознавство принаймні побіжно розглядали у своїх працях М. Бахтін, П. Берков, Л. Білецький, В. Всеволодський-Гернгросс, М. Гарбузюк, В. Гусєв, А. Дьомін, О. Клековкін, Г. Костюк, Д. Лихачов, Р. Пилипчук, Л. Приходько, Д. Шторгін, Г. Хайченко та ін. Однак упроваджені Перетцем методологічні принципи дослідження історії театру радше позначаються, ніж аналізуються.

Мета дослідження - визначити методологічні прийоми Володимира Перетца на основі аналізу головних його праць із історії театру. 
Виклад основного матеріалу. Одна з найістотніших особливостей ставлення Перетца до методології дослідження, котра відстежується в усіх його працях — «воля до методу».

Найголовнішими працями Перетца у царині методології були «Из лекций по методологии истории русской литературы» (1914) i «Краткий очерк методологии истории русской литературы» (1922). Обидві праці, попри істотні відмінності, широко обговорювалися науковою спільнотою, їм було присвячено кілька рецензій у вигляді окремих книжкових видань [5], і сьогодні ці дослідження (особливо останнє) мають високий індекс посилань. Дослідження Перетца, безперечно, здійснено в рамках історико-філологічної науки, та, проте, це були перші в Російській імперії та СРСР праці, в яких було враховано інтерес дослідника до історії театру.

Розглянувши одинадцять методів дослідження, Перетц поділив їх на об'єктивні (історичний, історико-психологічний (біографічний), культурно-історичний, естопсихологічний, порівняльно-історичний, еволюційний, філологічний) і неприйнятні для нього суб'єктивні (естетичний, етичний, публіцистичний, історико-політичний), тобто ангажовані власними або груповими смаками, етичними або естетичними уподобаннями дослідника. Відкидаючи суб'єктивні уподобання, наукові конвенції й актуальні соціальні проблеми («ідеології - змінюються, факти - залишаються» [6]), Перетц закликав до поленезалежності (що можна зіставити з ідеями його сучасників - феноменологічною редукцією Е. Гуссерля, «остранением» В. Шкловського та ін.) і зосереджує увагу на найпростіших питаннях фундаментальної науки: як це було насправді, що це було насправді, як це зроблено?

Відокремлюючи науку від публіцистики, Перетц вважав, що «примітивним видом вивчення [літератури] була літературна критика» $[7,13]$. На перший погляд, це твердження суперечить біографії самого Перетца, який виступав як театральний рецензент на шпальтах київських газет, однак насправді йдеться про розмежування критики й академічної науки: «Різниця між “суб'єктивним" та “об'єктивним" в нашій науці, саме - в прийомах $<\ldots>$. Констатування явищ $<\ldots>$ визначення iii генези - одне; оцінка цих явищ - естетична, моральна - інше $<. .>$ чи не найбільшою помилкою $\epsilon$ суміш цих двох прийомів - підміна судження оцінкою» $[8,19]$. Не вважаючи критику мертвим жанром, Перетц піддавав сумніву методи, на які вона спиралася: «Коли виявилося, що і суспільні, втім, як і художні смаки, — перехідні та мінливі, - стало неможливим $<\ldots>$ користуватися прийомами імпресіоністичної критики» $[9,43]$.

Визначаючи свій метод дослідження як філологічний, Перетц описував його як процес «вивчення пам'яток літератури з боку їхньої мови, способу передачі, походження, часу та місця виникнення, способу проникнення ззовні в дане літературне середовище», а також широко спирався на дані суміжних наук: «бібліографії, палеографії, історії мови, хронології, історії суспільних та історії релігійних поглядів, історії літератур античних, слов'янських і західноєвропейських народів, історії мистецтва» $[7,52]$. Віддаючи перевагу у власних працях історичному, порівняльному, філологічному та біографічному методам, інколи в межах одного дослідження, Перетц застосовував одразу декілька 3 них; тож не випадково Михайло Бахтін вважав праці Перетца «взірцем академічного еклектизму» $[10,237]$.

Незважаючи на те, що намір спиратися на той або інший метод оголошували й сучасники Перетца (приміром, Іван Стешенко і Володимир Рєзанов а питання методології дослідження історії театру ставили у своїх працях Дмитро Антонович, Олександр Кисіль і Петро Рулін), коло питань, на які вони шукали відповіді, отже, й процедурні аспекти їхніх досліджень, істотно відрізнялися. Це змушує зосередити увагу саме на операційних питаннях, на реалізованих Перетцем у своїх працях методологічних принципах і відповідних «сценаріях дослідження» («характері і послідовності запитань, 3 якими різні дослідники звертаються до минулого театру, а також способи, якими намагаються отримати правдиві відповіді» $[11,131])$.

Ледь не найяскравішим жанром, в якому реалізувалася у Перетца «воля до методу», були рецензії на праці колег, що посідають значне місце не лише у науковій спадщині науковця, а й у тогочасній гуманітаристиці в цілому. Рецензії В. Перетца на дослідження істориків театру формально можна розділити на дві категорії: інформативні та аналітичні, хоча навіть в «інформативні» рецензії Перетц завжди вносив аналітичний елемент.

До інформативних його рецензій належить коротеньке повідомлення 1901 року — «Н. М. Петровский. К истории русского театра» (1901). Рецензія містить загальні відомості про опублікований матеріал (місце, час написання, жанр, автор). У цій праці, що за обсягом не перебільшує півсторінки, показовим є використання філологічного (формального) методу дослідження, завдяки якому Перетц робить припущення про місце проживання вважали, що спираються на порівняльний метод, 
автора комедії [12, 154-155]. У наступній рецензії «В. Ф. Миллер. Новый интерлюдий XVIII в. СПб. 1900» (1901) Перетц, виходячи за межі жанру рецензії, визначає інтерлюдії як «зародки народної комедії» $[13,201]$, розширює список джерел i, аналізуючи стиль текстів, типологію персонажів, сюжетні лінії, встановлює зв'язок «між південним та північним репертуаром інтерлюдій» $[13,202]$.

До аналітичних належать рецензії Перетца на праці М. Дашкевича, І. Шляпкіна, Вс. Всеволодського-Гернгросса, а також «Новый труд по истории украинского театра». Першу дискусію в цьому жанрі Перетц ініціював 1894 року з приводу літературних джерел опери Івана Котляревського «Москаль-Чарівник». Перетц, охарактеризувавши рецензоване дослідження Дашкевича як «вельми цікаве», однак, не надто зупиняючись на чеснотах праці, виявив інше літературне джерело опери Котляревського «малоросійську народну казку» $[14,549]$.

Рецензія на працю Іллі Шляпкіна «Царевна Наталья Алексеевна и театр ее времени» (1899) $\epsilon$ найбільш схвальною з усього опрацьованого доробку Перетца у цьому жанрі. Власні критичні зауваження Перетц обмежив додаванням нових архівних документів [15, 540].

У рецензії 1915 року на дослідження Всеволодського-Гернгросса Перетц акцентує важливість обраної теми, відзначає вдалий спосіб викладення матеріалу (за царюваннями), переказує зміст кожного розділу і переходить до недоліків, серед яких: неповне використання доступних джерел, акцент на матеріальній стороні вистави $[16,211]$ (це зауваження Перетца доволі показове, адже у своїх подальших працях вчений виступатиме саме за вивчення образотворчої, матеріальної сторони вистави); спотворення змісту текстів, питання щодо концепції $[16,212]$ та висновків $[16,219]$. Загалом схвальний відгук Перетца можна пояснити тим, що підхід Всеволодського-Гернгросса до вивчення історії театру (робота з першоджерелами, залучення широкого кола допоміжних матеріалів, локалізація теми) та його погляди на історію театру (насамперед, розмежування театру і літератури) були суголосні принципам самого Перетца.

Найтривалішою, довжиною в кілька десятиліть, стала дискусія Перетца з Володимиром Рєзановим, початок якій поклала рецензія Перетца «Новый труд по истории украинского театра» (1911). Ця рецензія $\epsilon$ не менш важливою публікацією, ніж самостійні розвідки Перетца, адже критичні коментарі та зауваження, викладені у ній, як і сама структура рецензії, більш чітко унаочнюють методологічні принципи та прийоми побудови дослідження Пе- ретца. Свою рецензію науковець розпочинає часто повторюваною ним тезою про неможливість побудови загальної історії театру на даному етапі існування театрознавства. Після цього подає загальний огляд літератури, присвяченій вивченню як європейського, так і російського театру. Й особливо зупиняється на театрі українському, де відчувається, на думку Перетца, нестача «історико-літературного аналізу на фоні загальної еволюції театру Свропи» $[17,4]$. Здійснивши короткий переказ праці Рєзанова, Перетц переходить до аналізу окремих частин, що включає: загальну характеристику плану праці та змісту кожної частини; використані і пропущені, але необхідні для дослідження, джерела; самостійність дослідження (порівняння висновків Рєзанова з більш ранніми працями, співвідношення нових і вже відомих даних); функціональність (принципи побудови дослідження та завдання - систематизація, класифікація даних, принципово нове дослідження); принципи аналізу; недоліки (перенасиченість допоміжним (чорновим) матеріалом; тематичні та методологічні прогалини $[17,9,13,31,41]$ тощо.

Того ж року Рєзанов видрукував відповідь, в якій намагався спростувати більшість зауважень Перетца, зокрема, стосовно закиду про невикористану іконографію він писав: «B < ..> різдвяних драмах мотив про піднесення подарунків [до якого Перетц пропонує застосувати іконографічний аналіз] повністю відсутній < ..> в такому випадку зачіпати гіпотези проф. Перетца про вплив іконографії у мене не було жодного приводу» [18, 142-143] та ін.

Дискусія між ученими затягнулася на кілька десятиліть і дістала надзвичайно емоційний характер, що, зокрема, свідчить про те, що Рєзанов зачепив найгостріші для Перетца питання наукової етики та методології дослідження. Незважаючи на критику, Перетц віддавав належне Рєзанову як одному з перших, хто почав досліджувати театр, а не літературу [19, 223].

Зауваження Перетца у рецензії, що вийшла 1926 року в «Известиях отделения русского языка и словесности» [20], Рєзанов охарактеризував як «тенденційно-суб'єктивні»: «...[Перетц] з усією вагою свого академічного авторитету мокрим рядном напавсь на початкові випуски, люто пориваючися усяко $<\ldots>$ зганити видання» $[21,227]$. Більшість висунутих Перетцем зауважень стосувалися форми викладу матеріалу (дроблення п'єс, вибірковість представлених текстів, нехтування правилами видання тощо); фактичних помилок у виданих текстах [20, 373]; повторів власного дослідження минулих років [20, 382]; і головне - методологічної некомпетентності («своєрідне розуміння “порівняльного 
методу”, який зводиться до примітивного підбору паралелей...» [20, 381]). Лише з останнім зауваженням Рєзанов частково погодився: «Порівняльний матеріял, “параллели” поки що доводиться лиш призбирувати; генетичну залежність українських обробок од західноєвропейських пощастить сконстатувати $<\ldots>$, лише тоді, коли стануть приступні тексти $<\ldots>$ старовинного театру польського...» $[21,230]$.

На цьому дискусія не завершилася. Видрукувавши «Вимушену відповідь» у Записках історико-філологічного відділу, Перетц ще раз перелічив недоліки праці Рєзанова (розділивши їх на 12 пунктів), навів нові приклади недбалості у дослідженні Рєзанова і завершив сподіванням, що «читач сам розбереться в тому, оскільки мої зауваження $<\ldots>>$ “тенденційно-суб' єктивні”» [22, 328].

Дискусія між Перетцем і Рєзановим привернула до себе увагу широкого кола дослідників театру, а згодом втягнула їх у полілог, адже йшлося не лише про ставлення до публікації Рєзанова, а й про методологію театрознавчого дослідження. Пропагуючи чіткість поставлених завдань і методів, Перетц обстоював принцип дослідження локальних питань історії театру, розкладання явища на елементи, вивчення матеріальних елементів театру, методологічну гнучкість. На відміну від Перетца, Рєзанов виходив із необхідності видання великого масиву інформації, з метою якнайшвидшого написання загальної історії українського театру. Питання поглибленого аналізу, концепції та чіткості відходили для нього на другий план, вчений лише намічав екстремуми історії театрального мистецтва, нерідко помиляючись через відсутність повноцінного дослідження окремих питань i, на думку Перетца, недостатнього для такої роботи рівня знань. Крім питань наукової етики, дискусія виявила два принципи дослідження, що панували на початку XX ст., в українському театрознавстві, — індуктивний (В. Перетц) і дедуктивний (В. Рєзанов).

На відміну від багатьох його сучасників (Д. Антонович, О. Кисіль, П. Рулін та ін.), котрі зосереджували увагу здебільшого на видатних історичних явищах, включаючи сучасність, територією історичного дослідження для Перетца було лише хронологічно віддалене минуле (не раніше початку XIX століття), чітко локалізоване, котре зазвичай сприймалося як неактуальне, узбіччя. Виступаючи проти досліджень, темою яких була близька до дослідника епоха, Перетц казав: «Все, що відноситься до XIX століття - дуже близьке до нас, і спроби опрацювання літературного матеріалу за цей період неминуче хиблять через надмірну сторонність, суб'єктивність, і <..> вже занадто далеко стоять від самого скромного ідеалу науковості» [23, с. 22]. Цей принцип корелює 3 поленезалежністю, адже чим ближчий у часі об'єкт до дослідника, тим важче історикові залишатися неупередженим.

За відсутності достатньої кількості накопичених історичних фактів, вважав Перетц, говорити про створення «синтетичної історії» передчасно. Приділяючи увагу дослідженню локальних фактів, Перетц подеколи розкладав їх на елементи; він не намагався охопити досліджуване явище у цілому, зосереджуючи увагу на одному із його аспектів, якому зазвичай відповідало чітко сформульоване питання. Цей принцип можна виявити навіть у ранніх працях Перетца (історичний нарис, персоніфіковані й енциклопедичні статті), в яких, у звичній формі подієвої історії, він реалізує нові принципи дослідження.

Історичний нарис «Кукольный театр на Руси» (1895) - єдина монографія у театрознавчій спадщині Перетца. У цьому дослідженні Перетц одним із перших звернув увагу не на «високий» театр, а на явища низової культури, поставивши завдання «дати огляд вистав театру ляльок в Росії» $[24,3]$. До роботи він залучив широке коло допоміжного матеріалу: журнальні статті, записки мандрівників, щоденники, лубочні картинки, схеми театрів, гравюри тощо. Саме ж дослідження включає огляд історії європейського театру ляльок (зміна функції маріонеток, розвиток жанрів, європейська модель вертепу); театру ляльок в Росії (репертуар постійних театрів ляльок і гастролерів, рівень зацікавленості глядачів), вертепної драми України та Білорусії (джерела походження, час появи; принципи побудови, роботи ляльок і вертепної коробки (можливі сценічні ефекти); сюжет, актори; вплив українського вертепу на російський $[24,73])$; стадії «переробки вертепних вистав» $[24,78]$. Попри те, що праця була доволі критично зустрінута вчителем Перетца О. Соболевським («великий недолік: немає особистого знайомства. У Вас Петрушка - лише те, що у Ровинського, і те, що в Алфьорова; але можна було б сказати, далебі, вдесятеро більше» (Цит. за $[25,179])$, вона по праву вважається класикою театрознавства театру ляльок.

Персоніфіковані статті Перетца зосереджено на творчій постаті та їі доробку («А. С. Грибоедов и его ранние произведения» (1895), «Иван Андреевич Крылов как драматург» (1895)). Цей тип досліджень, крім есеїстичного стилю викладу, об'єднує чітко сформульована проблема, оголошена на початку дослідження («Що було причиною подібної маси суджень, іноді навіть суперечливих, про цю п’єсу 
Грибоєдова [“Лихо з розуму”] та її героя?» [26, 171]; «Під чиїм впливом перебував Крилов? Хто 3 трагічних і комічних письменників слугував зразком і прикладом для драматурга-початківця?» [27, 51]). Ці питання $є$ типовими для праць В. Перетца, в яких учений намагається простежити зв'язок між творчістю того або іншого автора і смаками його сучасників. Аналіз драматургії включає у Перетца: визначення дати написання твору та періоду творчості автора, до якого належить п'єса; переказ сюжету; характеристику історичних прототипів і самих персонажів; відомості про акторів, які першими виконували ролі у п’єсі; стиль п’єси («Грибоєдов не належав до жодної школи. Але якщо можна щось відзначити в < ..> п’єсі, то лише одну чисто класичну особливість <...> дотриману єдність в усіх трьох актах» $[26,175]$; «Усі персонажі < ..> говорять природною народною мовою» $[27,6])$; коментарі глядачів і критиків. Статті були написані на початку дослідницької кар'єри Перетца. Більше персоніфіковані дослідження з історії театру він не друкуватиме, так само як не повертатиметься до тем XIX-XX століття, обстоюючи думку, що ставлення дослідника до «актуального» матеріалу $\epsilon$ упередженим.

На момент виходу першої енциклопедичної статті (1896) Перетц ще не мав високого академічного статусу, тож підставою для такої пропозиції авторитетного видавництва «Брокгауз та Ефрон» двадцятишестирічному дослідникові мали бути праці вченого. Загалом, Перетц написав три енциклопедичні статті, присвячені театру: «Марионетки», «Раек» та «Русская драма». Статті написано за однією схемою, що містить: загальні відомості (визначення [28, 29]; всі значення терміна [28]); походження (історія появи і назви; період і джерела походження $[30,29]$; перші згадки в різних країнах [153]); літературну складову (зміна функції, репертуар [28, 29, 30]); жанрову систему [30, 29]; загальну характеристику текстів - сюжет, принцип побудови, основні герої; роль європейської драми та театру в Російській імперії, порівняння зі шкільною драмою [30]); матеріальну складову (принципи гри, устрій) [28, 30, 29]; мову вистав і виконавців [30].

До цього ж типу досліджень належать публікації стародруків, непретензійний жанр, який, однак, посідав помітне місце у науковій спадщині Перетца. Наукову публікацію рукописів і стародруків науковець вважав важливим підготовчим етапом дослідження. Цей жанр, на думку Перетца, дає можливість, шляхом порівняння з іншими творами, виявити, звідки було запозичено сюжет, або довести оригінальність твору, тобто простежити його генезу. Перетц не намагався дійти якогось конкретного висновку, розглядаючи такі публікації як спробу накопичення і класифікації матеріалів $[31,188]$. Однак, на відміну від перших публікацій у цьому жанрі [32; 33], у пізніших працях він істотно розширив коментар, подеколи подаючи лише найпоказовіші уривки тексту, натомість акцент переніс із самого віднайденого тексту на ті факти, що з нього можна видобути [34; $35 ; 36 ; 37]$. Коментар Перетца стосується відомостей про рукопис (місце зберігання, кількість сторінок, стан, імовірний автор, характеристика його почерку); особливостей сюжету (як характеристика жанрової природи); функцій окремих частин тексту, мовних характеристик (визначення часу, місця написання, призначення для певного типу театру, оригінальність твору) [34, 122]); особливостей сценічного втілення (Перетц подає ремарки автора «наче програму дій, вочевидь, для керівництва виконавцям» $[35,62])$; паралелей та запозичень, руху традицій (від колядок до релігійних віршів [36]). Показово, що це чи не єдиний жанр, в якому дослідження Перетца не позбавлене суб'єктивних оцінок («нудна суперечка» $[35,58]$, «чорт тут з'являється істотою простуватою та довірливою» [35, 60], «нездогадливий син» $[35,60]$, «інтерлюдія дає живу, опуклу картинку народного життя» [35, 60], «простакуватий чоловік» $[35,61]$, «як понуре відлуння, звучать ці жалібні вигуки Диявола та Смерті» [35, 62], «чи не найвдаліша і оригінальна п'єса зі збірника» [37, 276]). Незважаючи на певну обмеженість публікацій цього жанру, саме в цьому форматі Перетц вперше впроваджує нову для історії театру методологію. У праці «Властолюбивый образ человеколюбия Божия» [35], «Акт о Сарпиде, дуксе Ассирийском» [34] використовує ремарки як інструмент для визначення образотворчої складової вистави, а саме як вказівки для режисера й акторів; іконографічний матеріал - у дослідженні «Скоморошьи вирши» [39]; ставить під сумнів панівні концепції доби (наголошуючи на взаємозв' язку літературних явищ і народної творчості, відмежовується від популярної на той час концепції народництва, віддаючи домінантну роль літературі освічених верств [36; 37]).

Нарешті абсолютно новим, запозиченим із етнографії, був жанр анкети, представлений у театрознавчій спадщині Перетца публікацією «Письмо в редакцию» $([40,187])$, що згодом була повторена. У цій публікації виявлено один із найяскравіших методологічних прийомів дослідника. Серед інших, у цій анкеті Перетц ставить такі питання: «I. Чи існує в тій місцевості, де ви живете постійно або тимчасово, ляльковий театр: а) релігійний (вертеп, 
бетлейка, шопка) або б) світський (“Петрушка" або щось у такому самому дусі) < . . > II. Яке ставлення a) місцевих жителів і б) головним чином — поліції до вистав, що показуються? < . .> III. Хто зазвичай займається устроєм та показом ляльок? а) національність, віросповідання, вік, ім'я та прізвища показувачів та музиканта < ..>; б) від кого засвоїли це мистецтво показувач < .. > Винагорода, яку вони отримують? IV. Який устрій лялькового театру: сцени та ляльок? <..>. V. Якою мовою ведуться вистави? Їхній зміст? <..>. VI. Чи існує у вашій місцевості панорама (райок)? Повідомте його устрій $<\ldots>$, а також текст? $<\ldots>$ У кого навчаються райошники?» [40, 34-36]. Анкета була своєрідною формою відповіді Перетца на питання про те, чим $€$ вистава, які ознаки вона має та в який спосіб ці ознаки можна визначити. Опосередковано питання, що їх ставить Перетц, можна визначити як завдання вивчення лялькового театру.

Значне місце у театрознавчій спадщині Перетца належить історичним дослідженням, змістом яких було полемічне спростування поширених міфів. Зазвичай у цих публікаціях Перетц ставить під сумнів загальноприйняте твердження або ж спростовує його, обгрунтовуючи власну позицію. На початку полемічної статті Перетц формулює тезу, яку надалі піддає сумніву: «... початок свій театр в Росії отримав тільки з 1756 р. за ініціативою Федора Волкова 3 товаришами» [41, 181]; «Кажучи про початок театральних вистав на Вкраїні покликуються зазвичай на свідчення видатного українського письменника, атонського ченця Івана Вишенського, а власне на його лист р[оку] 1606» [42, 14]; у дослідженні «До історії вертепної драми» Перетц ставить під сумнів залежність українського вертепу від польської шопки $[43,2]$; у праці «Театральні ефекти в старовинному українському театрі» - перевірці підлягає традиція сприйняття шкільного театру як схоластичного, нудного і малопривабливого для глядачів [44]. Шляхи дослідження в цих працях відрізняються, як і отримані результати (в одному випадку - сформульоване твердження, що спростовує загальноприйняту думку [41], в іншому поставлено нове запитання [43]).

Так, у статті «Найдавніша згадка про театр на Україні», розглядаючи відоме свідчення Вишенського про перші вистави на етнічній території України, Перетц ставить запитання: «... чи існував так само і в український школі звичай влаштовувати вистави під час Вишенського, чи він писав про це на Атоні - 3 людського поговору?» [42, 15]. Взявши за основу українські та польські стародруки, Перетц доводить, що ще у 1560-1570 pp. подібні думки висловлювалися як в українських, так і польських полеміках, а Вишенський, як «вчений експерт в справі про книгу П. Скарги на користь Унії», не міг не знати їх. Окрім цього, Перетц вказує на відсутність збережених драматичних творів цього періоду. Наприкінці праці Перетц висуває власне припущення: «чи не $\epsilon$ напад Вишенського - лише літературне явище» $[42,15]$ і ставить запитання: «чи можливо $з$ певністю сказати, що слова Вишенського про “строющих и играющих комедії” стосуються до українських шкіл його часу?» $[42,15]$.

Іншу працю В. Перетца «До історії вертепної драми» було спровоковано дослідженням І. Франка. Вона містить «декілька думок про методу досліду над вертепом» $[43,2]$. Перетц ставить під сумнів залежність українського вертепу від польської шопки і висуває власний критерій достовірності даних: «Навіть коли ми наперед приймемо за аксіому присутність польського впливу $<\ldots>$, то було б великою методологічною помилкою не спробувати перевірити сю “аксіому” об' єктивними даними < .. > Нам здається потрібним $<\ldots>$ перед констатуванням якого небудь “впливу”, визначити в вертепній драмі все, що могло би бути роз'яснене даними місцевого побуту та обряду. Тільки “нерозпускальний останок”, <..>, може бути основою, щоб з певністю говорити про присутність того або іншого “впливу”» $[43,2]$. Намагаючись встановити час появи вертепної драми в Україні, Перетц збирає відомості про розташування персонажів, аналізує малярські правила написання ікон i, власне, іконографічний матеріал («церковна іконографія <...> була <..> неминучим і вірним шаблонам, згідно з яким автор i режисер містерії розміщав на сцені свої персонажі, одягав їх в те чи інше вбрання, надавав відповідні їх стану та ролі атрибути» $[43,4])$. Коментуючи зміст зображень, Перетц розташовує збережені пам'ятки у хронологічній послідовності, порівнює ïx із європейськими зразками, простежує еволюцію «схеми» зображень i, зважаючи на те, що «нічого від старинної іконографії < ..> [вертеп] не зберіг у своїй обстанові, а скористався тим, що надавала західно-європейська католицька іконографія» [43, 14], робить висновок: вертеп у Україні з'явився не раніше початку XVII століття. Цією працею, на думку Р. Пилипчука, Перетц «руйнував систему доказів І. Франка», спираючись «на вельми плідну» думку, що український вертеп тісно пов'язаний 3 іконографією [45, 268].

У праці «Театральні ефекти в старовинному українському театрі» Перетц ставить завдання «оцінити історичну вагу шкільного театру» $[44,16]$ і для характеристики естетичної цінності шкільного 
театру використовує прийоми формального аналізу: «Очевидно - i ми змушені припустити це - в самій будові й розкладі дії, в засобах іiї сценічного втілення були такі елементи й такі сценічні засоби та способи, які діяли і на виконавців, і на глядачів умисно чи ні $<\ldots>$, підбадьорювали увагу глядачів, викликаючи в них естетичні емоції театрального порядку» $[44,16]$. Перетц наголошував: «кожна театральна форма творила свої засоби, які утримували увагу глядача і загострювали його сприйняття» $[44$, 17]. Під засобами сценічної дії Перетц розуміє сценічні ефекти, виявленню яких і присвячує подальше дослідження. Усі засоби шкільної драми він поділяє на дві категорії: авторські (закладені драматургом) і театральні (створені режисером, актором, бутафором). Спираючись на аналіз ремарок та авторського тексту, Перетц створює функціональну класифікацію, де для кожної групи ефектів наводить приклади іiї використання, інколи з цитуванням, інколи з переказом: ефекти дії (переодягання, крадіжка, бійка, смерть, танці, пародії; ефекти глядні (польоти у повітрі, масові сцени; «замало було розповісти про події та чудеса хоч би в найживішому діалогу: треба було поставити їх перед очі» $[44,20]) ;$ світлові ефекти (вогонь, феєрверки); згукові ефекти (грім, глас Божий, луна, плачі, співи, акцент). Крім того, Перетц також намагається встановити джерела походження шкільної драми (сюжетів і сценічних ефектів) в Україні.

Нарешті у кількох програмних працях Перетц формулює методологічні принципи і завдання театрознавчого дослідження.

У статті «К постановке изучения старинного театра в России» (1923) [46] дослідник формулюе завдання вивчення старовинного театру, зокрема: створення бібліографії театрального мистецтва, визначення сюжетів та літературних стилів п'єс, окреслення теоретичних уявлень «про завдання театру, побудову п'єси, реалізацію задумів автора актором, режисером та іншими працівниками театру» [19, 224], накопичення відомостей про устрій, організацію театру та акторів, реконструкція образотворчого аспекту вистави.

Праця «Несколько мыслей о старинном русском театре» (1920) починається з фундаментального твердження як для методології Перетца, так і для його театрознавчих досліджень взагалі: російський театр сформулювався «внаслідок вторгнення чужої традиції < ..> Спроби вивести початок російського театру, що склався наприкінці XVII ст., до народного хорового дійства - неможливі» $[19,217]$. Перетц окреслює межі «запозичення»: «....наслідуванню, щоб переносити на свій театр чужі спочатку твори, потрібно мати всю ту суму культурник звичок, всю сукупність психічних навичок, котрі створюють характер людини, певної епохи та певного середовища» $[19,219]$. Далі Перетц характеризує типологічні ознаки старовинного театру: статичність («сталість типів, положень, драматичних форм, — і в методі сценічної реалізації думок драматурга, тобто у грі актора» $[19,220])$, умовність (схематичність, яку Перетц пояснює недостатнім професіоналізмом актора, психіка якого мала «наблизитись до психіки автора») [19, 221], примітивність драматургії.

У праці «К вопросу об основаниях научной литературной критики», спираючись на тезу про те, що «суспільні віяння та настрої, так само як і художні смаки, минущі та мінливі» $[9,43]$, Перетц демонструє власні критичні принципи, засновані на «аналізові прийомів композиції й образотворчих засобів» $[9,43]$, тобто на спробі типологізації явища. Ці авторські прийоми Перетц послідовно досліджує через типові ідеї (випадковість, рок, «жіноче питання» тощо), типових героїв (психологічна характеристика через мову - нечленороздільні звуки, спотворення слів) [9, 57], сюжетні мотиви («жінка зрадила чоловіка», «дівчина зваблена негідником» $[9,49]$ та ін.), засоби і способи викладу (сон або віщий сон, смерть дитини від дифтериту як рушій дії $[9,54]$ тощо).

Ще раз до питань методології Перетц звернувся в одному з останніх своїх досліджень - «К вопросу о сравнительном методе в литературоведении» (1934), в якому намагався окреслити можливості порівняльного методу і розглянути сам механізм запозичення у культурі [47].

Репресії проти Перетца, як свідчать документи ДПУ, було розпочато у зв'язку з його націоналістичною діяльністю [48]. Проте не менше підстав для репресій давала і методологія Перетца, про ставлення до якої з боку ідеологів марксизму свідчить, зокрема, видрукувана у журналі «Под знаменем марксизма» погромна рецензія на його «Короткий нарис методології...»: «Напрямок, який починається Бєлінським і через Чернишевського завершується марксизмом. < . .> Цей об'єктивний метод дослідження шановний академік забув включити дванадцятим до свого списку» [49].

Отже, попри те, що наукова спадщина В. Перетца у галузі історії театру представлена різними жанрами (статті, рецензії, монографії, публікації стародруків тощо), більшості його досліджень притаманні такі ознаки: «воля до методу»; поленезалежність; локалізація теми, їі хронологічна віддаленість; концептуальна чіткість у постановці локальних завдань і у висновках; аналіз понять, на 
яких базується дослідження і лексики досліджуваної доби; дослідження матеріального аспекту театру; домінування формального принципу аналізу; розкладання аналізованого явища на елементи; залучення до аналізу «непрямих свідків»; верифікація фактів і висновків; типологія замість міфологізованих «взірців»; аналіз стосунків виконавців і глядачів; методологічна гнучкість.

\section{Джерела та література}

1. Костюк Ю. Украинский театр // История театроведения народов СССР: Очерки. 1917-1941: Сб. / Отв. ред. Хайченко Г. М.: Наука, 1985. С. 12-24.

2. Королева Н. Древнерусский театр и театр XVIII века // История советского театроведения: Очерки. 1917-194 1: Сб. / Отв. ред. Хайченко Г. М.: Наука, 1981. С. 132-149.

3. Клековкін О. Школа Володимира Перетца. Театр при столику. Методологія театрознавства: Подорожній щоденник. ІПСМ НАМ України. К.: Фенікс, 2013. С. 152-211.

4. Демин А. Труды В.Н. Перетца по истории русского театра / Демин А. О древнерусском литературном творчестве: Опыт типологии с XI по середину XVIII вв. от Илариона до Ломоносова / отв. ред. Гребенюк В. М.: Языки славянской культуры, 2003. 760 с.

5. Архангельский А.Из лекций по истории русской литературы. Несколько заметок по поводу книги: проф. В.Н. Перетц. Из лекций по методологии истории русской литературы. Пг.: Самообразование, 1914. 32 с.

6. Перетц В. Лист до Н. П. Кистяківської. 26. 03. 1930 // Iнститут рукопису Національної бібліотеки Украӥни ім. В. I. Вернадського. Ф. 203. № 15.1 арк.

7. Перетц В.Краткий очерк методологии истории русской литературы: Пособие и справочник для преподавателей, студентов и для самообразования. Пг.: Academia, 1922. $164 \mathrm{c}$.

8. Перетц В. Из лекций по методологии истории русской литературы. История изучений. Методы. Источники. Корректурное издание на правах рукописи. Киев, 1914. 496 с.

9. Перетц В. К вопросу об основаниях научной литературной критики // Ученые записки Самарского университеma. Саратов, 1919. Вып. 2. С. 43-68.

10. П. Н. Медведев [М. М. Бахтин]. Формальный метод в литературоведении. Критическое введение в социологическую поэтику / Бахтин М. (под маской). Фрейдизм. Формальный метод в литературоведении. Марксизм и философия языка. Статьи. М.: Лабиринт, 2000. С. 186348 .

11. Клековкін О. Історіографія театру: Напрями. Школи. Методи. Постаті: Навчальний посібник. К.: АртЕк, 2017. $336 \mathrm{c}$.

12. Перетц В. [В. П.]. [рец.] Н. М. Петровский. К истории русского театра. Комедия о графе Фарсоне // Литературный вестник. СПб.: Типо-Литография А.Э. Варенке, 1901. T. II. Кн. VI. C. 154-155.

13. Перетц В. [рец.]. В.Ф. Миллер. Новый интерлюдий XVIII в. Спб. 1900 // Литературный вестник. СПб.: Типо-Литография А. Э. Варенке, 1901. Т. 1. Кн. II. С. 201235.

14. Перетц В. [рец.] К исследованию о литературном источнике оперы И.П. Котляревского «Москаль Чаривнык» // Киевская Старина. К.: Типография Императорского университета св. Владимира, 1894. Т. 44. № 3. C. $548-551$.
15. Перетц В. [рец.] И. А. Шляпкин. Царевна Наталья Алексееевна и театр ее времени, 189 // Журнал Министерства народного просвящения. СПб.: Типография «В.С. Балашев и $\mathrm{K}^{\circ} », 1899$. Ч. CCCXXIV. № 8. С. 538-549.

16. Перетц В. [рец.] В. Всеволодский-Гернгросс. Театр в России при императрице Анне Иоановне и императоре Иоанне Алексеевиче. СПб., 1914 // Журнал Министерства народного просвящения. Новая серия. СПб, 1915. Ч. LV. № 1. С. 205-221.

17. Перетц В.Новый труд по истории украинского театра. СПб.: Сенатская типография, 1911. 42 с.

18. Резанов В. Замечания на рецензию профессора В. Н. Перетца // Журнал министерства народного образования. Новая серия. СПб: Сенатская типография, 1911. Ч. XXXIV. № 7. C. 132-145.

19. Перетц В. Несколько мыслей о старинном русском театре // Ежегодник Петроградских государственных театров. Сезон 1918-1919. Пг., [б. в.], 1920. С. 217-225.

20. Перетц В. [рец.] Проф. В. Резанов. Драма українська. У Київі, 1926. I, 202 с.; III, 323 с. // Збірник історично-філологічного відділу Украӥнської Академії наук, ч. 7). Известия Отделения русского языка и словесности АH СССР. Л., 1926. Т. XXXI. С. 369-383.

21. Рєзанов В. 3 приводу рецензії акад. Вол. Перетца на: Проф. В. Рєзанов. Драма Українська, в.в. I, III. У Київі, 1926 // Записки історично-філологічного відділу Украӥнської Академії Наук. К.: Друкарня Української Академії Наук, 1927. Кн. XV. С. 227-230.

22. Перети В.Вимушена відповідь // Записки історично-філологічного відділу Украӥнської Академї Наук. К.: Друкарня Української Академії Наук, 1928. Кн. XVIII. С. 326-328.

23. Перетц В. Найближчі завдання вивчення історії української літератури // Записки Украӥнського наукового товариства в Києві. 1908. Кн. 1. С. 16-24.

24. Перетц В. Кукольный театр на Руси. Исторический очерк // Ежегодник императорских театров. Сезон 1893-1894. СПб.: Типография Императорских Санкт-Петербургских Театров, 1894. Приложение. Кн. 1. С. 85-185.

25. Робинсон М. Академик В. Н. Перетц - ученик и учитель // Славянский альманах. М., 2002. С. 178-236.

26. Перетц В.А.С. Грибоедов и его ранние произведения // Исторический вестник. СПб.: Типография А. С. Суворина, 1895. T. LIX. C. 171-176.

27. Перетц В. Иван Андреевич Крылов как драматург // Ежегодник императорских театров. Сезон 1893-1894. СПб.: Типография Императорских Санкт-Петербургских Театров, 1895. Приложение. Кн. 2. С. 1-54.

28. Перетц В. [В. П.]. Марионетки // Энциклопедический словарь Брокгауза и Ефрона: В 86 т. / Сост. Брокгауз Ф., Ефрон И. СПб.: Акц. общ. Брокгауз-Ефрон, 1896. Т. XVIIIa. C. 631-634.

29. Перетц В. [В. П.]. Раек // Энциклопедический словарь Брокгауза и Ефрона: В 86 т. / Сост. Брокгауз Ф., Ефрон И. СПб.: Акц. общ. Брокгауз-Ефрон, 1899. T. XXVI. С. 106.

30. Перетц В. [В. П.]. Русская драма // Энциклопедический словарь Брокгауза и Ефрона: В 86 т. / Сост. Брокгауз Ф., Ефрон И. СПб.: Акц. общ. Брокгауз-Ефрон, 1899. Т. XXVII. C. 300-303.

31. Перетц В. [рец.]. Нова метода вивчати казки (В. Пропп. Морфология сказки. Вопросы поэтики) // Етнографічний вісник. К.: Друкарня ВУАН, 1930. Кн. 9. С. 187-195.

32. Перетц В.Итальянские комедии и интермедии представленные при дворе императрицы Анны Иоанновны в 1733-1735. Пг.: Типография Имп. Академии Наук; К.: Типография 2-й Артели Печатников, 1917. 489 с.

33. Перетц В. Памятники русской драмы эпохи Петра Великого. СПб.: Издание Императорской Академии Наук, $1903.570 \mathrm{c}$. 
34. Перетц В. Акт о Сарпиде, дуксе Ассирийском // Известия Отделения русского языка и словесности. Пг., 1921. Т. XXVI. C. 103-123.

35. Перетц В.Властотворный образ человеколюбия Божия // Ежегодник императорских театров. Сезон 1897-1898. СПб.: Типография Императорских Санкт-Петербургских Театров, 1898. Приложения. Кн. 1. С. 55-78.

36. Перетц В. К истории польского и русского народного театра (Окончание) // Известия Отделения русского языка и словесности. СПб., [б. в.], 1911. Т. XVI. Кн. 4. С. 39-66.

37. Перетц В. К истории польского и русского народного театра, XVIII-XIX // Известия Отделения русского языка и словесности. СПб., [б. в.], 1911. Т. XVI. Кн. 3. С. 248-319.

38. Перетц В.Скоморошьи вирши по рукописи половины XVIII века // Отдельный оттиск из Ежегодника императорских театров. Сезон 1896-1897. СПб.: Типография главного управления Уделов, 1898. 19 с.

39. Перетц В. Письмо в редакцию // Киевская старина. К.: Типография Императорского университета св. Владимиpa, 1897. Т. 58. № 7-8, июль-авг[уст]. Отд. 2. С. 34-36.

40. 40. Перетц В. Из начального периода жизни русского театра // Известия отделения русского языка и словесности Императорской Академии наук. СПб.: Типография Императорской Академии Наук, 1908. Т. ХII. Кн. 3. С. 181-225.

41. 41. Перетц В.Найдавніша згадка про театр на Україні // Україна. К., 1924. Кн. 1-2. С. 14-15.

42. 42. Перетц В. До історії вертепної драми: Замітки та матеріали // Записки Наукового Товариства імені Шевченка / під ред. Грушевського М. Львів, Друк. Наук. Товариства ім. Шевченка, 1908. T. LXXXV. Кн. V. C. 5-20.

43. Перетц В. Театральні ефекти в старовинному українському театрі // Україна. К., 1926. Кн. 1. С. 16-33.

44. Пилипчук Р. До питання про початок українського вертепу, або Ще раз в обороні Еразма Ізопольського // Верховина. Дрогобич: Коло, 2003. С. 263-285.

45. Перетц В. К постановке изучения старинного русского театра // Cтаринный театр в России XVII-XVIII вв.: Сб. / Под ред. акад. Перетца В. Пг.: Academia, 1923. С. 7-33.

46. Перетц В. К вопросу о сравнительном методе в литературоведении // Труды отдела древнерусской литературы ИРЛИ. Л.: Академия наук СССР, 1934. Т. 1. С. 327-339.

47. Ксерокопии уголовного дела на Перетц Владимира Николаевича // Архів СБУ. Ф. 68. КДВ. 136. Спр. № 3906.365 с.

48. В. Р. [рец.] Акад. В. Н. Перетц. «Краткий очерк методологи истории русской литературы» // Под знаменем марксизма. М.: Материалист, 1922. № 4. С. 121-123.

\section{References:}

1. Kostyuk, Yu. (1985). Ukrainskiy teatr // Istoriya teatrovedeniya narodov SSSR: Ocherki. 1917-1941: Sb. / Otv. red. Khaychenko G. Moscow: Nauka. S. 12-24

2. Koroleva, N. (1981). Drevnerusskiy teatr i teatr XVIII veka // Istoriya sovetskogo teatrovedeniya: Ocherki. 1917-1941: Sb. / Otv. red. Khaychenko G. Moscow: Nauka. - S. 132149 [in Russian].

3. Klekovkin, O. (2013). Shkola Volodumura Perettsa. Teatr pry stolyku. Metodolohiia teatroznavstva: Podorozhnii shchodennyk / IPSM NAM Ukrainy. Kyiv: Feniks, 2013. S. 152-211 [in Ukrainian].

4. Demin, A. (2003). Trudy V. N. Perettsa po istorii russkogo teatra // Demin A. O drevnerusskom literaturnom tvorchestve: Opyt tipologii s XI po seredinu XVIII vv. ot Ilariona do Lomonosova / Otv. red. Grebenyuk V. Moscow: Yazyki slavyanskoy kultury, 2003, 760 [in Russian].

5. Arkhangelskiy, A. (1914). Iz lektsiy po istorii russkoy literatury. Neskolko zametok po povodu knigi: prof. V.N.Peretts. Iz lektsiy po metodologii istorii russkoy literatury. Pg.: Samoobrazovanie. 32 s.
6. 6. Peretts, V. Lyst do N.P. Kystiakivskoi. 26. 03. 1930 // Instytut rukopysu Natsionalnoi biblioteky Ukrainy im. V.I. Vernadskoho. F. 203, № 15.1 ark.

7. Peretts, V. (1922). Kratkiy ocherk metodologi istorii russkoy literatury: Posobie i spravochnik dlya prepodavateley, studentov i dlya samoobrazovaniya. Pg.: Academia. $164 \mathrm{c}$.

8. Peretts, V. (1914). Iz lektsiy po metodologii istorii russkoy literatury. Istoriya izucheniy. Metody. Istochniki. Korrekturnoe izdanie na pravakh rukopisi. Kyuiv. $496 \mathrm{~s}$.

9. Peretts, V. (1919). K voprosu ob osnovaniyakh nauchnoy literaturnoy kritiki // Uchenye zapiski Samarskogo universiteta. Saratov. Vyp. 2. S. 43-68.

10. P. N. Medvedev [M. M. Bakhtin] (2000). Formalnyy metod v literaturovedenii. Kriticheskoe vvedenie v sotsiologicheskuyu poetiku // Bakhtin M. (pod maskoy). Freydizm. Formalnyy metod v literaturovedenii. Marksizm i filosofiya yazyka. Statti. M.: Labirint. S. 186-348.

11. Klekovkin, O. (2017). Istoriohrafiia teatru: Napriamy. Shkoly. Metody. Postati: Navchalnyi posibnyk. K.: ArtEk. 336 s.

12. Peretts, V. [V. P.] (1901). [rets.] N. M. Petrovskiy. K istorii russkogo teatra. Komediya o grafe Farsone// Literaturnyy vestnik. SPb.: Tipo-Litografiya A. E. Varenke. T. II. Kn. VI. S. 154-155.

13. Peretts, V. [rets.]. (1900). V. F. Miller. Novyy interlyudiy XVIII v. Spb. // Literaturnyy vestnik. SPb.: Tipo-Litografiya A. E. Varenke, 1901. T. 1. Kn. II. S. 201-235.

14. Peretts, V. [rets.] (1894). K issledovaniyu o literaturnom istochnike opery I. P. Kotlyarevskogo «Moskal Charivnyk» // Kievskaya Starina. K.: Tipografiya Imperatorskogo universiteta sv. Vladimira. T. 44. № 3. S. 548-551.

15. Peretts V. [rets.] (1899). I. A. Shlyapkin. Tsarevna Natalya Alekseeevna i teatr ee vremeni. 1898 // Zhurnal Ministerstva narodnogo prosvyashcheniya. SPb.: Tipografiya «V.S. Balashev i Ko». Ch. CCCXXIV. № 8. S. 538-549.

16. Peretts, V. [rets.] (1915). V.Vsevolodskiy-Gerngross. Teatr $\mathrm{V}$ Rossii pri imperatritse Anne Ioanovne i imperatore Ioanne Alekseeviche. SPb, 1914 // Zhurnal Ministerstva narodnogo prosvyashcheniya. Novaya seriya. SPb. Ch. LV. № 1. S. 205-221.

17. Peretts, V. (1911). Novyy trud po istorii ukrainskogo teatra. $\mathrm{SPb}$.: Senatskaya tipografiya. $42 \mathrm{~s}$.

18. Rezanov, V. (1911). Zamechaniya na retsenziyu professora V.N.Perettsa // Zhurnal ministerstva narodnogo obrazovaniya. Novaya seriya. SPb.: Senatskaya tipografiya. Ch. XXXIV. № 7. S. 132-145.

19. Peretts, V. (1920). Neskolko mysley o starinnom russkom teatre // Yezhegodnik Petrogradskikh gosudarstvennykh teatrov. Sezon 1918-1919. Pg., [b. v.]. S. 217-225.

20. Peretts, V. [rets.] (1926). Prof. V. Rezanov. Drama ukraïnska. U Kiivi, 1926. I, 202 str.; III, 323 s. (Zbirnik istorichnofilologichnogo viddilu Ukraïnskoï Akademiï nauk, ch. 7) // Izvestiya Otdeleniya russkogo yazyka i slovesnosti AN SSSR. L. T. XXXI. S. 369-383.

21. Riezanov, V. (1927). Z pryvodu retsenzii akad. Vol. Perettsa na: Prof. V. Riezanov. Drama Ukrainska, v. v. I, III. U Kyivi, 1926 // Zapysky istorychno-filolohichnoho viddilu Ukrainskoi Akademii Nauk. K.: Drukarnia Ukrainskoi Akademii Nauk. Kn. XV. S. 227-230.

22. Peretts, V. (1928). Vymushena vidpovid // Zapysky istorychno-filolohichnoho viddilu Ukrainskoi Akademii Nauk. K.: Drukarnia Ukrainskoi Akademii Nauk. Kn. XVIII. S. 326-328.

23. Peretts, V. (1908). Naiblyzhchi zavdannia vyvchennia istorii ukrainskoi literatury // Zapysky Ukrainskoho naukovoho tovarystva v Kievi. Kn. 1. S. 16-24.

24. Peretts, V. (1894). Kukolnyy teatr na Rusi. Istoricheskiy ocherk // Yezhegodnik imperatorskikh teatrov. Sezon 18931894. SPb.: Tipografiya Imperatorskikh Sank-Peterburgskikh Teatrov. Prilozhenie. Kn. 1. S. 85-185.

25. Robinson, M. (2002). Akademik V. N. Peretts - uchenik i uchitel // Slavyanskiy almanah. Moscow. S. 178-236. 
26. Peretts V. (1895). A. S. Griboedov i ego rannie proizvedeniya // Istoricheskiy vestnik. SPb.: Tipografiya A. S. Suvorina. T. LIX. S. 171-176.

27. Peretts, V. (1895). Ivan Andreevich Krylov kak dramaturg // Yezhegodnik imperatorskikh teatrov. Sezon 1893-1894. $\mathrm{SPb}$. Tipografiya Imperatorskikh Sankt-Peterburgskikh Teatrov. Prilozhenie. Kn. 2. S. 1-54;

28. Peretts, V. (1896). [V. P.]. Marionetki // Entsiklopedicheskiy slovar Brokgauza i Yefrona: V 86 t. / Sost. Brokgauz F., Yefron I. SPb.: Akts. Obshch. Brokgauz-Yefron. T. XVIIIa. S. 631-634.

29. Peretts, V. (1899). [V. P.]. Raek // Entsiklopedicheskiy slovar Brokgauza i Yefrona: V 86 t. / Sost. Brokgauz F., Yefron I. $\mathrm{SPb} .:$ Akts. Obshch. Brokgauz-Yefron. T. XXVI. S. 106.

30. Peretts, V. (1899). [V. P.]. Russkaya drama // Entsiklopedicheskiy slovar Brokgauza i Yefrona: V 86 t. / Sost. Brokgauz F., Yefron I. SPb.: Akts. Obshch. BrokgauzYefron. T. XXVII. S. 300-303.

31. Peretts, V. [rets.] (1930). Nova metoda vyvchaty kazky (V. Propp. Morfolohyia skazky. Voprosy poetyky) // Etnohrafichniy visnyk. K.: Drukarnia VUAN. Kn. 9. S. 187-195.

32. Peretts, V. (1917). Italyanskie komedii i intermedii predstavlennye pri dvore imperatritsy Anny Ioannovny v 1733-1735. Pg.: Tipografiya imp. Akademii Nauk; K. Tipografiya 2-y Arteli Pechatnikov. 489 s.

33. Peretts, V. (1903). Pamyatniki russkoy dramy epokhi Petra Velikogo. SPb.: Izdanie Imperatorskoy Akademii Nauk. 570 s.

34. Peretts, V. (1921). Akt o Sarpide, dukse Assiriyskom // Izvestiya Otdeleniya russkogo yazyka i slovesnosti. Pg.. T. XXVI. S. 103-123.

35. Peretts, V. (1898). Vlastotvornyy obraz chelovekolyubiya Bozhiya // Yezhegodnik imperatorskikh teatrov. Sezon 1897 1898. SPb.: Tipografiya Imperatorskikh Sankt-Peterburgskikh Teatrov. Prilozheniya. Kn. 1. S. 55-78.

36. Peretts, V. (1911). K istorii polskogo i russkogo narodnogo teatra (Okonchanie) // Izvestiya Otdeleniya russkogo yazyka i slovesnosti. SPb., [b. v.]. T. XVI. Kn. 4. S. 39-66.
37. Peretts, V. (1911). K istorii polskogo i russkogo narodnogo teatra, XVIII-XIX // Izvestiya Otdeleniya russkogo yazyka i slovesnosti. SPb., [b. v.]. T. XVI. Kn. 3. S. $248-319$.

38. Peretts, V. (1898). Skomoroshi virshi po rukopisi poloviny XVIII veka// Otdelnyy ottisk iz Yezhegodnika imperatorskikh teatrov. Sezon 1896-1897. SPb.: Tipografiya glavnogo upravleniya Udelov. $19 \mathrm{~s}$

39. Peretts, V. (1897). Pismo v redaktsiyu // Kievskaya starina. K.: Tipografiya Imperatorskogo universiteta sv. Vladimira. T. 58. № 7-8, iyul-avg[ust]. Otd. 2. S. 34-36.

40. Peretts, V. (1908). Iz nachalnogo perioda zhizni russkogo teatra // Izvestiya otdeleniya russkogo yazyka $i$ slovesnosti Imperatorskoy Akademii nauk. SPb.: Tipografiya Imperatorskoy Akademii Nauk. T. XII. Kn. 3. S. 181-225.

41. Peretts, V. (1923). K postanovke izucheniya starinnogo russkogo teatra // Starinnyy teatr v Rossii XVII-XVIII vv.: Sb. / Pod red. akad. Perettsa V. Pg.: Academia. S. 7-33.

42. Peretts, V. (1924). Naidavnisha zghadka pro teatr na Ukraini // Ukraina. Kiev. Kn. 1-2. S. 14-15.

43. Peretts, V. (1908). Do istorii vertepnoi dramy: Zamitky ta materialy // Zapysky Naukovoho Tovarystva imeni Shevchenka / Pid red. Hrushevskoho M. Lviv, Druk. Nauk. Tovarystva im. Shevchenka. T. LXXXV. Kn. V. S. 5-20.

44. Peretts V. (1926). Teatralni efekty v starovynnomu ukrainskomu teatri // Ukraina. Kiev. Kn. 1. S. 16-33.

45. Pylypchuk, R. (2003). Do pytannia pro pochatok ukrainskoho vertepu, abo shche raz v oboroni Erazma Izopolskoho // Verkhovyna. Drohobych: Kolo. S. 263-285.

46. Peretts, V. (1924). K voprosu o sravnitelnom metode v literaturovedenii // Trudy otdela drevne-russkoy literatury IRLI. L.: Akademiya nauk SSSR. T. 1. S. 327-339.

47. Kserokopii ugolovnogo dela na Peretts Vladimira Nikolaevicha // Arkhiv SBU. F. 68. KDV. 136. Spr. № 3906. $365 \mathrm{~s}$.

48. V. R. [rets.] (1922). Akad. V. N. Peretts. «Kratkiy ocherk metodologi istorii russkoy literatury» // Pod znamenem marksizma. M.: Materialist. № 4. S. 121-123. 